\title{
PREDICTIVE MODELING OF OFFICE RENT IN SELECTED DISTRICTS OF ABUJA, NIGERIA
}

\author{
Namnso Udoekanem, Ph.D \\ Department of Estate Management and Valuation \\ Federal University of Technology, Minna, Niger State, Nigeria \\ e-mail:namnsoudoekanem@futminna.edu.ng \\ James Ighalo, Ph.D \\ Department of Estate Management \\ Bells University of Technology, Ota, Nigeria \\ Yekeen Sanusi, Ph.D \\ Department of Urban and Regional Planning \\ Federal University of Technology, Minna, Niger State, Nigeria
}

\begin{abstract}
This study examined the drivers of office rents in selected districts of Abuja, Nigeria. These districts are Asokoro, Maitama and Utako. Primary and secondary data were utilized for the study. Primary data include office rental levels and office space data in the study areas for the period 2001-2012, and were obtained through structured questionnaires administered to real estate surveying and valuation firms which are active in the commercial property markets in the study areas. Secondary data for the study were obtained from the National Bureau of Statistics (NBS) and the Central Bank of Nigeria $(\mathrm{CBN})$, and consist mainly of macroeconomic variables in Nigeria during the study period. Using single-equation regression analysis, the developed office rent model accounted for $76 \%, 72 \%$ and $75 \%$ of the variation in office property rents in the commercial property market of the Asokoro, Maitama and Utako districts respectively. The study also revealed that real GDP growth and vacancy rate are the major determinants of rental growth in the office property market in the districts of Asokoro and Maitama, while real GDP growth is the major driver of office rents in the Utako district. The socioeconomic implication of the findings is that the government can generate substantial revenue from property rate through sustained commercial property rental performance in the study areas. Such revenue can be deployed to provide and maintain public infrastructure, thereby improving the wellbeing of the citizenry.
\end{abstract}

Key words: Office Rental Determinants; Office Property Market; Office Rent Model; Nigeria

JEL Classification: G3, M14

Citation: Udoekanem N., Ighalo J., Sanusi Y., 2015, Predictive Modeling of Office Rent in Selected Districts of Abuja, Nigeria, Real Estate Management and Valuation, Vol. 23, No. 4, pp. 95-104.

DOI: $10.1515 /$ remav-2015-0040

\section{Introduction}

In land economic theory, rent is an important concept. Since the beginning of organized land settlement, rental payments have been made for the use of land. These payments represent the economic return as compensation for their use in production (BARLOWE 1986). The collapse of feudalism as a socio-political and economic system led to a rise in individual enterprises, rights and 
responsibilities. This facilitated private ownership of property and, consequently, the leasing of such properties to generate periodic income in the form of rent. In modern times, the origin of rent has been traced to the origin of the private ownership of property. Rent is also the price of land and a payment made by tenant farmers to landlords for the use of the soil. As a factor of production, classical economists over the years have attempted to analyze the economic concept of land, the role of land in the production process and the nature of land rent. This analysis was initially based on agricultural production and was gradually extended to include other land uses.

Rent from land could also be viewed as an unearned monopoly return which land owners could claim because of the institution of private property (BARLOWE 1986). However, most investors and real property owners, in contrast, see rent as a return on the capital value of their real estate investments and compare these returns with those they could receive from alternative capital investments. On the other hand, tenants view rental payments as an operating cost (BARLOWE 1986).

The commercial property market is defined by some fundamental concepts. These concepts provide the basis for the determination of commercial property rental values. ARCHER and LING (1997) established a three market framework, illustrating the relationships between the space market, the property market and the capital market. Thus, in the commercial property market, rental value is a function of demand and supply factors. That is:

$$
R=f(D+S)+e
$$

where:

$R-$ commercial property rent

$D-$ demand factors

$S-$ supply factors

$e$ - error term

The composition of the individual characteristics of these factors varies in the context of national, regional and local commercial property markets. Measuring commercial property rental patterns is important as it provides information for making decisions about investing and developing, and can be used to predict the cyclical behavior of commercial property development (BORN \& PHYRR 1994).

The commercial property market has forward and backward linkages to the economy of any nation. According to OZYURT (2014), commercial property markets show significant interaction with macroeconomic activity and the stability of the financial markets. Most financial institutions worldwide depend on commercial property assets for their operations. Critical adjustments in the commercial property markets can exert a noticeable impact on commercial property rental performance and pricing. KURYJ-WYSOCKA, KURYJ and WISNIEWSKI (2014) argued that the dynamics of the property market should be understood as a change of property values under the influence of market and non-market factors. This also involves rental changes. RADZEWICZ, RENIGIER-BILOZOR and WISNIEWSKI (2011) observed that even the smallest of such changes may result in a random change in other elements of the real estate market system, thereby altering the relations and dependences occurring in the market. Thus, the property market is under constant change, depending on the behavior and activities of market participants, as well as the influence of the surrounding elements (RADZEWICZ 2013). CHIN (2003) investigated the relationship between macroeconomic factors and office rental movements in five Southeast Asian cities of Singapore, Hong Kong, Taipei, Kuala Lumpur, and Bangkok over the period 1988-2001.The study tested office rental value against some indicators of economic activity which have been used in previous empirical studies. The study also assessed the influence of six-demand-side variables, namely Real Gross Domestic Product (GDP), interest rates, prime lending rates, consumer price index, service sector output and unemployment rates, as well as one supply-side variable (changes in office floor space). The study revealed that changes in floor space and prime lending rates were the key determinants of office property rental values in the selected cities apart from Bangkok.

ORR and JONES (2003) focused their study on the analysis and prediction of local office rents and, in particular, the development of econometric models for two UK cities, Edinburgh and Glasgow. Their study reviewed the current state of modeling and forecasting for office markets and noted the scarcity of urban office rent models. They contended that urban models that exist suffer from data problems, and such models either make the fatal flaw of ignoring supply constraints or consider supply in terms of net change in floor space. The objective of their study was to address some of the deficiencies identified in existing empirical works on office market dynamics by using local take-up as a variable 
to model urban rents. Their study adopted two approaches to modeling urban office rents. The first model adopted a single reduced-form price equation using direct demand and supply measures and suggested that variation in market dynamics exists between the two centers. The second model is a three-equation "structural" model. The results of their analysis also suggest that Edinburgh responds more quickly to fundamental changes in supply-demand imbalances than Glasgow in the determination of office rents. The variation between Edinburgh and Glasgow, two cities within one administrative region of the UK, exemplifies the arguments in favor of urban analysis and the deficiencies in the regional approach to forecasting.

MCCARTNEY (2012) examined the short and long-run rent adjustment in the Dublin office market in Ireland. The study estimated a rent determination model for the office market in Dublin based on a two-stage error correction mechanism which involved the estimation of a long-run equilibrium rent equation and a short-run rent adjustment process. The result of the long-run analysis indicated that office demand is relatively inelastic in Dublin, while the short-run model indicated a relatively slow rate of rent adjustment in the Dublin office market.

Many property researchers and academics have developed a range of mathematical models for the purpose of forecasting rental trends in the commercial property market. Most of these models have been utilized in predicting office property rental trends (BOON \& HIGGINS 2007; TONELLI et al., 2004). Existing literature reviewed for the study reveals that models already developed by researchers for office rental growth forecasting are either a single equation model or multi-equation model.

The single equation model is based on the premise that property, economic and financial variables are used to capture the interaction within the framework of demand and supply (BOON \& HIGGINS 2007; COLWELl \& JACKSON 2004; DEWIT \& VAN DIJK 2003; D'ARCY et al. 1999; MCGOUGH \& TsOlacos 1999). The single equation model is also based on the assumption that rent is a linear function of a series of independent variables. Such a model could help explain the historical variation in rental values (dependent variable) and predict rental trends in the future (BOON \& HIGGINS 2007).

The multi-equation model comprises two or more equations which incorporate endogenous and exogenous variables used to model rental change, development markets and space demand changes (CHIN 2003). TONELLI et al. (2004); PARKER et al. (2003); MCGOUGH and TSOlACOS (1999); HENDERSHOTT et al. (1998); HEKMAN (1985) and ROSEN (1984) used the multi-equation model to predict commercial property rental growth over a given timeframe.

However, although using multiple equations has the ability to capture the dynamics of the property market more effectively than the single equation model because it integrates the influence of the exogenous variables and allows for an interaction between them and the endogenous variables within the system (MCGOUGH \& TsOlaCOS, 1999), such models based on theory have been found by STEVENSON and MCGARTH (2003) to limit flexibility in modeling, particularly when used for forecasting purposes. Rental growth forecast parameters are often incorporated into discounted cash flow models for property appraisals (BOON \& HIGGINS 2007). Findings from previous studies have shown that rental growth determinants vary from locality to locality (UDOEKANEM et al., 2014; BOON \& HigGins 2007; HUI \& YU, 2006; TONELLI et al., 2004; YUSOF 2001). This also implies that a commercial property rental model developed for one locality may be inappropriate for the assessment of commercial property rental performance in another due to variation in key rental determinants.

It is on this basis that the present study was carried out to develop a predictive model for commercial property rents in the Asokoro, Maitama and Utako districts of Abuja, Nigeria, based on the knowledge of the key drivers of commercial property rents in these districts. The specific objectives of the study are to:

1) ascertain the temporal changes in the rental values of office properties in the Asokoro, Maitama and Utako districts of Abuja, Nigeria;

2) assess the influence of macroeconomic variables and vacancy rates on office property rental movements in the study areas; and

3) formulate a model to predict rental movements in the study areas caused by the variables responsible for rental variations assessed in (2) above.

\section{Methodology and data}

This study utilized primary and secondary data. The primary data comprise rental data of office properties in the Asokoro, Maitama and Utako districts of Abuja, Nigeria. These include annual data 
on the rental levels for office properties under study for the period 2001-2012 and their specific characteristics, occupancy levels and property floor stock. Secondary data for the study are mainly data on macro-economic indices in Nigeria for the period under analysis. The annual statistical bulletins of the National Bureau of Statistics (NBS) and the Central Bank of Nigeria (CBN) were surveyed to extract relevant data on macro-economic indices in Nigeria for the period 2001-2012. These macro-economic indices are: the inflation rate, interest rate on real estate loans, interest rate on commerce, Monetary Policy Rate (MPR), Gross Development Product (GDP), Unemployment Rate, and Employment Rate. Accordingly to the aim of the study, only commercial investment properties were selected for data collection for the study as they constitute the only class of commercial properties for which rents are paid for occupation, and such rents undergo changes in the form of rental adjustment or rental growth. These properties are mainly office properties in the study areas. The rental data were obtained from estate surveying and valuation firms which are active in the commercial property market in the city of Abuja. The sample size for each of the districts was determined quantitatively using the FRANKFORT-NACHMIAS (1996) model for sample size determination as follows:

$$
n=\frac{Z^{2} p q N}{e^{2}(N-1)+Z^{2} p q}
$$

where:

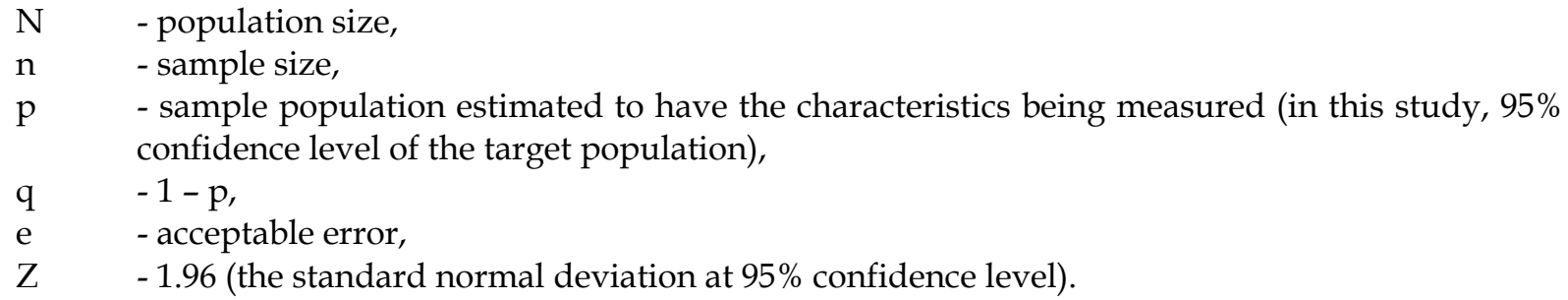
The districts, number of office properties with the required data and number of office properties sampled have been presented in Table 1.

Table 1

Districts, number of office properties with required data, and number of office properties sampled in the study area

\begin{tabular}{ccc}
\hline District & $\begin{array}{c}\text { Number of Office Properties } \\
\text { with Required Data }\end{array}$ & $\begin{array}{c}\text { Number of Office Properties } \\
\text { sampled }\end{array}$ \\
\hline Asokoro & 34 & 23 \\
Maitama & 47 & 29 \\
Utako & 37 & 25 \\
\hline Total & 118 & 77 \\
\hline
\end{tabular}

Source: own study.

Using a systematic random sampling technique, 77 office properties were selected from a total of 118 office properties in the study areas which have the required data. Office property rents used for the study were standardized relative to their superficial floor areas. This standardization limited the quantum of office property rental data for the study as rental data on office properties which could not be accessed to determine their superficial floor areas were eliminated. Also, there were some gaps in the available data on rents paid by property occupiers on office properties in the study areas in the past 10 years. This is because the estate surveying and valuation firms which were respondents to the questionnaire were not in charge of the management of the properties during the period and, as such, had no knowledge of the rents that were paid. An attempt was made to close these gaps by determining the weighted rent for office properties in each district for each of the years under study.

\section{Results and discussion}

The weighted rent $/ \mathrm{m}^{2}$ of office properties in the commercial property market selected for the study is presented in Table 2. The rental index was constructed based on the weighted rent $/ \mathrm{m}^{2}$ of office properties in the commercial property market selected for the study using 2001 as the base year, as presented in Table 4 . The result of rental index analysis for office properties in the various commercial 
property markets in the study areas indicates an upward trend in the rental values of office properties in the selected districts within the study period as shown in Figure 1.

Table 2

Rental levels for office properties in the study areas, 2001 - 2012

\begin{tabular}{|c|c|c|c|c|c|c|}
\hline \multirow{2}{*}{$\begin{array}{c}\text { Commercial } \\
\text { Property } \\
\text { Market }\end{array}$} & \multicolumn{6}{|c|}{ Weighted Office Rental Value/m² in $\mathbf{N}^{\prime} 000(€ 1=\mathbf{N} 202)$} \\
\hline & 2001 & 2002 & 2003 & 2004 & 2005 & 2006 \\
\hline Asokoro & 13.05733 & 13.68067 & 14.21333 & 15.02067 & 16.77333 & 21.374 \\
\hline Maitama & 11.097 & 13.23545 & 15.0421 & 15.0887 & 15.8406 & 20.2242 \\
\hline \multirow[t]{2}{*}{ Utako } & 8.294167 & 9.555 & 10.4394 & 11.7612 & 11.9744 & 12.9395 \\
\hline & 2007 & 2008 & 2009 & 2010 & 2011 & 2012 \\
\hline Asokoro & 23.53813 & 26.20118 & 27.92944 & 30.06632 & 32.1381 & 35.19783 \\
\hline Maitama & 20.279 & 22.5405 & 24.6513 & 25.0648 & 26.92444 & 32.26 \\
\hline Utako & 13.7875 & 14.65286 & 14.96682 & 15.96304 & 16.48875 & 20.0484 \\
\hline
\end{tabular}

Source: own study.

The rental growth factor for each year under study was calculated as the quotient of the weighted rent $/ \mathrm{m}^{2}$ in the following year and the weighted rent $/ \mathrm{m}^{2}$ in the preceding year. The average rental growth rate for office properties in the study areas for the period 2001-2012 was determined using the geometric mean model, based on the natural logarithmic values of the weighted rent $/ \mathrm{m}^{2}$. The rental growth factor for office properties in Asokoro, Maitama and Utako for the period, 2001-2012 was 1.0835-1.1019. This represents an average rental growth rate of $8.35 \%-10.19 \%$ for the study period, as presented in Table 3.

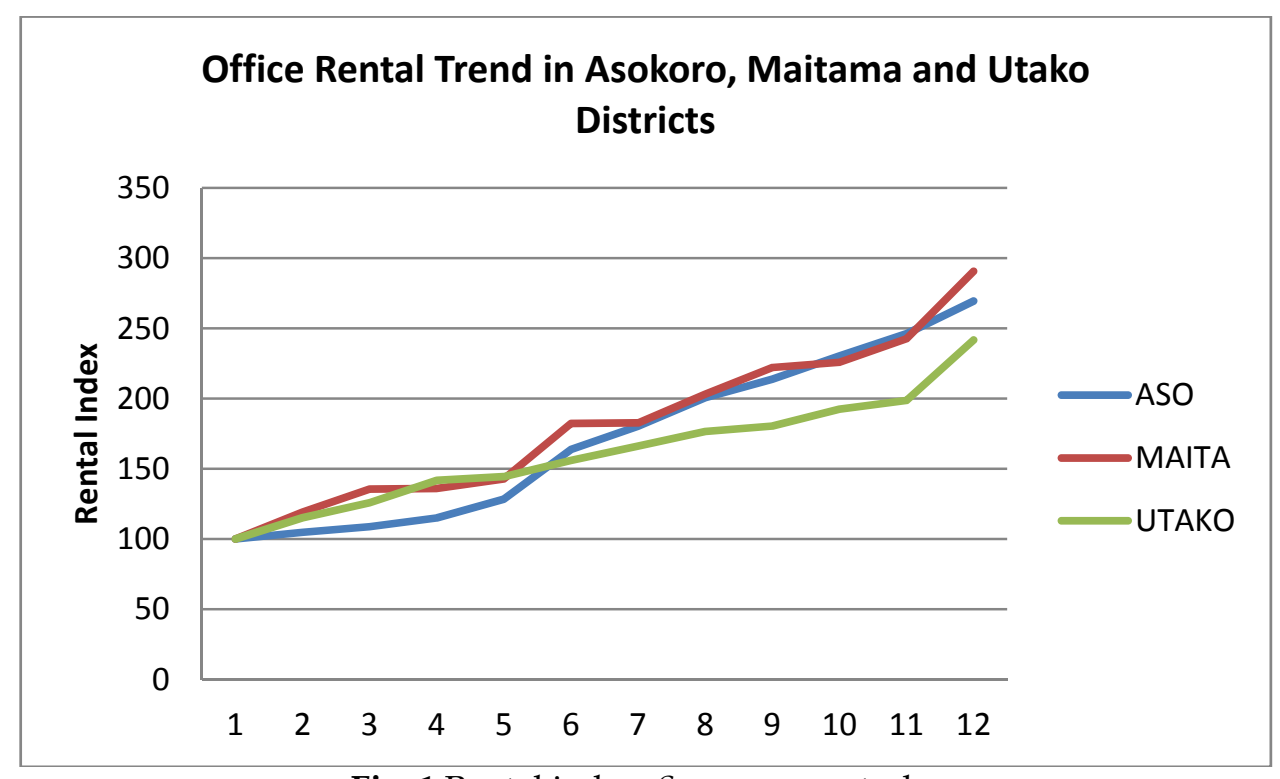

Fig. 1 Rental index. Source: own study.

Table 3

Office rental change, rental growth factor, and average rental growth rate for office properties in the study areas, 2001-2012

\begin{tabular}{ccccc}
\hline $\begin{array}{c}\text { Commercial } \\
\text { Property } \\
\text { Market }\end{array}$ & Rental Change & Slope & $\begin{array}{c}\text { Rental Growth } \\
\text { Factor }\end{array}$ & $\begin{array}{c}\text { Average Rental } \\
\text { Growth Rate (\%) } \\
\text { (2001-2012) }\end{array}$ \\
\hline Asokoro & 0.9916 & 0.0901 & 1.0943 & 9.43 \\
Maitama & 1.06715 & 0.0970 & 1.1019 & 10.19 \\
Utako & 0.882597 & 0.0802 & 1.0835 & 8.35 \\
\hline
\end{tabular}

Source: own study. 
Table 4

Rental index for office properties in the study areas, 2001-2012

\begin{tabular}{ccccccc}
\hline $\begin{array}{c}\text { Commercial } \\
\text { Property } \\
\text { Market }\end{array}$ & $\mathbf{2 0 0 1}$ & $\mathbf{2 0 0 2}$ & $\mathbf{2 0 0 3}$ & $\mathbf{2 0 0 4}$ & $\mathbf{2 0 0 5}$ & $\mathbf{2 0 0 6}$ \\
\cline { 2 - 7 } & & & & & & \\
\hline Asokoro & 100 & 104.77 & 108.85 & 115.04 & 128.46 & 163.69 \\
Maitama & 100 & 119.27 & 135.55 & 135.97 & 142.75 & 182.25 \\
Utako & 100 & 115.20 & 125.86 & 141.80 & 144.37 & 156.01 \\
& $\mathbf{2 0 0 7}$ & $\mathbf{2 0 0 8}$ & $\mathbf{2 0 0 9}$ & $\mathbf{2 0 1 0}$ & $\mathbf{2 0 1 1}$ & $\mathbf{2 0 1 2}$ \\
Asokoro & 180.27 & 200.66 & 213.90 & 230.26 & 246.13 & 269.56 \\
Maitama & 182.74 & 203.12 & 222.14 & 225.87 & 242.63 & 290.71 \\
Utako & 166.23 & 176.66 & 180.45 & 192.46 & 198.80 & 241.72 \\
\hline
\end{tabular}

Source: own study.

Vacancy rates for office properties in the study areas for the period 2001-2012 were determined as presented in Table 5 . This was based on the office space data for the study areas.

Table 5

Office vacancy rates in the study areas, 2001-2012

\begin{tabular}{ccccccc}
\hline $\begin{array}{c}\text { Commercial } \\
\text { Property } \\
\text { Market }\end{array}$ & $\mathbf{2 0 0 1}$ & $\mathbf{2 0 0 2}$ & $\mathbf{2 0 0 3}$ & $\mathbf{2 0 0 4}$ & $\mathbf{2 0 0 5}$ & $\mathbf{2 0 0 6}$ \\
\cline { 2 - 7 } & & & & & & \\
\hline Asokoro & 46.65 & 38.62 & 32.93 & 28.31 & 24.07 & 18.51 \\
Maitama & 28.7 & 23.65 & 34.89 & 23.18 & 26.79 & 23.63 \\
Utako & 28.86 & 36.48 & 38.87 & 29.11 & 23.93 & 24.85 \\
& 2007 & $\mathbf{2 0 0 8}$ & $\mathbf{2 0 0 9}$ & $\mathbf{2 0 1 0}$ & $\mathbf{2 0 1 1}$ & $\mathbf{2 0 1 2}$ \\
Asokoro & 14.71 & 13.05 & 11.26 & 9.05 & 6.48 & 4.03 \\
Maitama & 17.44 & 16.06 & 14.07 & 11.98 & 11.46 & 9.87 \\
Utako & 21.68 & 20.3 & 18.87 & 17.86 & 16.31 & 11.99 \\
\hline
\end{tabular}

Source: own study.

Macroeconomic data collected for the study were based on the macroeconomic variables identified from the existing literature reviewed for the study. These variables include the interest rate on general commerce, interest rate on real estate loans, inflation rate, monetary policy rate, unemployment rate, exchange rate, real GDP growth rate $_{L}$ and change in employment level. The Augmented Dicker Fuller (ADF) unit root test was carried out on all the data series to examine the extent of their stationarity. The results of the test have been presented in Table 6.

Table 6

Result of the stationarity test for data series utilized for the study

\begin{tabular}{lcc}
\hline \multicolumn{1}{c}{ Variable } & Computed ADF Statistic & Critical ADF Statistic at $\mathbf{\alpha}=\mathbf{0 . 0 5}$ \\
\hline$\Delta$ Office Vacancy Rate(Asokoro) & -4.9266 & -1.9755 \\
$\Delta \Delta$ Office Rent(Asokoro) & -3.8878 & -1.9835 \\
$\Delta$ Office Vacancy Rate(Maitama) & -4.5356 & -1.9791 \\
$\Delta \Delta$ Office Rent(Maitama) & -4.4107 & -1.9835 \\
$\Delta \Delta$ Office Vacancy Rate(Utako) & -2.7061 & -1.9835 \\
$\Delta \Delta$ Office Rent(Utako) & -4.7253 & -1.9835 \\
$\Delta$ Interest Rate on General Commerce & -6.000 & -1.9791 \\
$\Delta$ Interest Rate on Real Estate Loans & -5.8631 & -1.9791 \\
$\Delta$ Inflation Rate & -5.4785 & -1.9791 \\
$\Delta$ Monetary Policy Rate & -2.8953 & -1.9791 \\
$\Delta$ Unemployment Rate & -4.9116 & -1.9791 \\
$\Delta$ Exchange Rate & -3.1905 & -1.9791 \\
$\Delta$ Real GDP Growth Rate & -4.4665 & -1.9791 \\
$\Delta$ Employment Level & -6.4692 & -1.9791 \\
\hline
\end{tabular}

Source: own study. 
The computed ADF statistics are less than the critical value at 0.05 level, as presented in Table 6 . The implication of this is that the time series data on the variables utilized for the study are suitable for regression analysis. Also, based on the stationary nature of the time series data utilized for the study, the Granger causality test was applied to the data to assess the causal linkage between the explanatory variables explored for the study and office rental movements in the commercial property market under study. The result of the Granger causality test revealed that among all the explanatory variables explored in the study, only real GDP growth, vacancy rate and inflation rate were found to have a statistically significant causal linkage to office rental movements in the study areas and, as such, Granger cause office rental movements in the office property market in the analyzed areas as indicated in Table 7.

Table 7

Result of Granger causality test between the suggested explanatory variables and office rental movements in the study areas, 2001-2012

\begin{tabular}{lccc}
\hline & \multicolumn{3}{c}{ F-Statistics } \\
\cline { 2 - 4 } INTGC does not Granger Cause Office Rent & ASOKORO & MAITAMA & UTAKO \\
INTREL does not Granger Cause Office Rent & $(0.98344)$ & $(0.13138)$ & $(0.80986)$ \\
& $(1.77931$ & 1.19848 & 0.26087 \\
INR does not Granger Cause Office Rent & 5.74062 & $(0.30549)$ & $(0.62331)$ \\
& $(0.04345)^{*}$ & $(0.02824)^{*}$ & $(0.03373)^{*}$ \\
MPR does not Granger Cause Office Rent & 0.00402 & 0.24478 & $3.70 \mathrm{E}-05$ \\
& $(0.95101)$ & $(0.63408)$ & $(0.99528)$ \\
UNEMP does not Granger Cause Office Rent & $2.10 \mathrm{E}-05$ & 2.83307 & 0.14747 \\
& $(0.99646)$ & $(0.13084)$ & $(0.71097)$ \\
EXCHR does not Granger Cause Office Rent & 0.43684 & 0.01103 & 1.59043 \\
Real GDP does not Granger Cause Office & $(0.52722)$ & $(0.91895)$ & $(0.2428)$ \\
Rent & 4.90722 & 6.97162 & 8.46145 \\
EMP does not Granger Cause Office Rent & $(0.03157)^{*}$ & $(0.01431)^{*}$ & $(0.01645)^{*}$ \\
& 0.35386 & 1.59625 & 1.17192 \\
VACR does not Granger Cause Office Rent & $(0.56838)$ & $(0.24201)$ & $(0.31055)$ \\
& 4.86741 & 7.06431 & 6.23146 \\
\end{tabular}

The $p$-values are in parentheses

*Significant at a level of 0.05

INTGC= Interest Rate on General Commerce; INTREL = Interest Rate on Real Estate Loans; INR = Inflation Rate; MPR = Monetary Policy Rate; UNEMP = Unemployment Rate; EXCHR = Exchange Rate; EMP = Changes in Employment Level; $V A C R=$ Office Vacancy Rate.

\section{Source: own study.}

Consequently, explanatory variables with no statistically significant causal linkage were dropped while those with statistically significant causal linkage were utilized to develop a regression model for office property rents in the commercial property markets under study. The regression analysis was based on the theoretical framework of the commercial property rent equation in which commercial property rent is assumed to be a linear function of demand and supply factors in the commercial property market. The results of the regression analysis have been presented in Table 8 .

Table 8

Results of the regression analysis

\begin{tabular}{ccccccccc}
\hline $\begin{array}{c}\text { Commercial } \\
\begin{array}{c}\text { Property } \\
\text { Market }\end{array}\end{array}$ & Term & Coefficient & $\begin{array}{c}\mathbf{t}- \\
\text { Stat. }\end{array}$ & $\mathbf{p}-$ Value & Tolerance & VIF & $\mathbf{R}^{2}$ & SE \\
\hline Asokoro & Intercept & 4.748 & 23.68 & $<0.0001$ & & & 0.76 & 0.20757 \\
& $\Delta \mathrm{INR}_{\mathrm{t}-2}$ & 0.004512 & 0.05 & 0.9599 & 0.4902 & 2.0400 & & \\
& $\mathrm{ARGDP}_{\mathrm{t}-1}$ & 0.6146 & 3.70 & 0.0060 & 0.4188 & 2.3878 & \\
& $\Delta \mathrm{VACR}_{\mathrm{t}-1}$ & -0.2414 & -3.43 & 0.0089 & 0.7342 & 1.3620 & &
\end{tabular}




\begin{tabular}{ccccccccc} 
Maitama & Intercept & 4.723 & 24.23 & $<0.0001$ & & & 0.72 & 0.20114 \\
& $\Delta \mathrm{INR}_{\mathrm{t}-2}$ & 0.01918 & 0.23 & 0.8256 & 0.4903 & 2.0396 & & \\
& $\Delta$ RGDP $_{\mathrm{t}-1}$ & 0.6323 & 3.43 & 0.0090 & 0.3185 & 3.1397 & & \\
& $\Delta \mathrm{VACR}_{\mathrm{t}-1}$ & -0.2232 & -2.36 & 0.0457 & 0.4752 & 2.1044 & & \\
\multirow{6}{*}{ Utako } & & & & & & & & \\
& Intercept & 4.67 & 32.41 & $<0.0001$ & & & 0.75 & 0.14648 \\
& $\Delta \mathrm{INR}_{\mathrm{t}-2}$ & 0.04603 & 0.74 & 0.4788 & 0.4806 & 2.0807 & & \\
& $\Delta$ RGDP $_{\mathrm{t}-1}$ & 0.4625 & 3.48 & 0.0083 & 0.3262 & 3.0656 & & \\
& $\Delta \mathrm{VACR}_{\mathrm{t}-1}$ & -0.1521 & -2.15 & 0.0637 & 0.4237 & 2.3602 & & \\
\hline
\end{tabular}

Source: own study.

For Asokoro, the office rent model is:

$$
\text { ORent }=4.748+0.0045 I N R_{t-2}+0.6146 R G D P_{t-1}-0.2414 V A C R_{t-1}+e_{t}
$$

The Durbin-Watson Statistic for the model is 1.14. This is above its critical value at 0.05 level $(0.658)$ and shows that residual serial correlation was not statistically significant in the model. Again, the collinearity statistics, that is the tolerance and Variance Inflation Factor (VIF), are within acceptable statistical limits. This implies that the predictor variables for the model have no problem of multicollinearity. The $76 \%$ variation in office property rents in the commercial property market in Asokoro is also explained by the model. In addition, real GDP growth and vacancy rate are the significant drivers of rental change in the commercial property market in Asokoro. Although inflation rate Granger causes office rental movements in the area within the period under study, its influence in predicting office property rents in the area is insignificant. Thus, a unit increase in real GDP growth will produce a 0.6146 increase in office rents in Asokoro, while a unit increase in vacancy rate will produce a 0.2414 decrease in office rents in the area. Also, a unit increase in inflation will produce a 0.004512 increase in office rents in the commercial property market in Asokoro.

For Maitama, the office rent model is:

$$
\text { ORent }=4.723+0.0192 I N R_{t-2}+0.6323 R G D P_{t-1}-0.2232 V_{V A C R} R_{t-1}+e_{t}
$$

The Durbin-Watson Statistic for the model is 1.21. This exceeds its critical value at 0.05 level $(0.658)$ and shows that residual serial correlation was not statistically significant in the model. Again, the collinearity statistics, that is the tolerance and Variance Inflation Factor (VIF), are within acceptable statistical limits. This implies that the predictor variables for the model have no problem of multicollinearity. Also, the $72 \%$ variation in office property rents in the commercial property market in Maitama is explained by the model. In addition, real GDP growth and vacancy rate are the significant drivers of rental change in the commercial property market in Maitama. Although inflation rate Granger causes office rental movements in the area within the period under study, again its influence in predicting office property rents in the area is insignificant. Thus, a unit increase in real GDP growth will produce a 0.6323 increase in office rents in Maitama, while a unit increase in vacancy rate will produce a 0.2232 decrease in office rents in the area. Also, a unit increase in inflation will produce a 0.01918 increase in office rents in the commercial property market in Maitama.

For Utako, the office rent model is:

$$
\text { ORent }=4.67+0.046 I N R_{t-2}+0.4625 R G D P_{t-1}-0.1521 V_{\text {VACR }}+e_{t-1}
$$

The Durbin-Watson Statistic for the model is 1.11. This exceeds its critical value at 0.05 level (0.658) and indicates that residual serial correlation was not statistically significant in the model. Again, the collinearity statistics, that is the tolerance and Variance Inflation Factor (VIF), are within acceptable statistical limits. This implies that the predictor variables for the model have no problem of multicollinearity. Also, the $75 \%$ variation in office property rents in the commercial property market in Utako is explained by the model. Furthermore, real GDP growth is the significant driver of rental change in the commercial property market in Utako. Although vacancy rate and inflation rate Granger cause office rental movements in the area within the period under study, their influence in predicting office property rents in the area is insignificant. Thus, a unit increase in real GDP growth will produce a 0.4625 increase in office rents in Utako, while a unit increase in vacancy rate will produce a 0.1521 
decrease in office rents in the area. Also, a unit increase in inflation will produce a 0.04603 increase in office rents in the commercial property market in Utako.

The significance of the regression models was tested using the F-test. The computed F-statistic for the office rent model for office property rents in all the commercial property markets in the selected districts is significant at a p-value of less than 0.05 , as presented in Table 9. This indicates that the office rent model for the districts under study fits the data utilized and, as such, can be used as a basis for the prediction of office property rents in the commercial property market in the study areas.

Table 9

Results of the test for the statistical significance of the regression models

\begin{tabular}{|c|c|c|c|c|c|c|}
\hline $\begin{array}{c}\text { Commercial } \\
\text { Property } \\
\text { Market }\end{array}$ & $\begin{array}{c}\text { Source } \\
\text { of } \\
\text { Variation }\end{array}$ & $\begin{array}{c}\text { Sum } \\
\text { of } \\
\text { Squares }\end{array}$ & DF & $\begin{array}{l}\text { Mean } \\
\text { Square }\end{array}$ & F-Statistic & p - Value \\
\hline \multirow[t]{3}{*}{ Asokoro } & Model & 1.09948 & 3 & 0.36649 & 8.51 & 0.0072 \\
\hline & Residual & 0.34467 & 8 & 0.04308 & & \\
\hline & Total & 1.44415 & 11 & & & \\
\hline \multirow[t]{3}{*}{ Maitama } & Model & 0.81821 & 3 & 0.27274 & 6.74 & 0.0140 \\
\hline & Residual & 0.32367 & 8 & 0.04046 & & \\
\hline & Total & 1.14188 & 11 & & & \\
\hline \multirow[t]{3}{*}{ Utako } & Model & 0.51390 & 3 & 0.17130 & 7.98 & 0.0086 \\
\hline & Residual & 0.17166 & 8 & 0.02146 & & \\
\hline & Total & 0.68556 & 11 & & & \\
\hline
\end{tabular}

Source: own study.

\section{Conclusion}

Based on single-equation regression analysis, the office rent model developed accounted for $76 \%, 72 \%$ and $75 \%$ of the variation in office property rents in the commercial property market in the Asokoro, Maitama and Utako districts respectively. The study also revealed that real GDP growth and vacancy rate are the major determinants of rental growth in the office property market in the Asokoro and Maitama districts, while real GDP growth is the major driver of office rents in Utako district. The findings of this study on real GDP and vacancy rate as the major drivers of office rental change are consistent with those of previous empirical studies on the subject in other regions of the world, such as CHIN (2003); HUI and YU (2006); BOON and HIGGINS (2007) and McCARTNEY (2012). This confirms that real GDP growth and vacancy rate are major factors for office space demand and office space supply respectively.

In addition, knowledge of the key drivers of commercial property rental change in any city in Nigeria is necessary to enable national and international investors to make informed decisions on their commercial property investments in these cities. This requires consistent and reliable commercial property market analysis to obtain up-to-date indicators that influence rental movements in the property market in these cities at any given time. In order to achieve this, the Federal Government through the Central Bank of Nigeria (CBN) and the National Bureau of Statistics (NBS) should ensure that statistics on macroeconomic indicators for the country, such as real GDP, unemployment rate, employment rate, interest rate, and inflation rate, are published on a state and city basis. This will enhance the determination of key drivers of commercial property rental change that are reliable and can interpret the reality of the commercial property markets in these locations.

\section{References}

ARCHER, W. R., LING, D.C., 1997, The Three Dimensions of Real Estate Markets: Linking Space, Capital and Property Markets, Journal of Real Estate Finance (fall), pp. 7 - 14.

BARLOWE, R., 1986, Land Resource Economics, $4^{\text {th }}$ Edition, New Jersey, Prentice Hall.

BoON, F.N., Higgins, D., 2007, Modelling the Commercial Property Market: An Empirical Study of the Singapore Office Market, Pacific Rim Property Research Journal, Vol. 13, No. 2, pp. 176 193. 
BorN, W. L., PyHrR, S. A., 1994, Real Estate Valuation: The Effect of Market and Property Cycles, Journal of Real Estate Research, Vol. 9, No. 4, pp. 455 - 486.

CHIN, H. W., 2003, Macro-economic Factors Affecting Office Rental Values in Southeast Asian Cities: The Case of Singapore, Hong Kong, Taipei, Kuala Lumpur and Bangkok, Paper presented at the 9th Pacific Rim Real Estate Society Conference held in Brisbane, Australia.

Colwell, P.F., JACKSON, C., 2004, Modelling Rental Changes Across Key Retail Investment Market in Britain, Journal of Property Investment and Finance, Vol. 22, No. 5, pp. $354-385$.

D'ARCy, E., McGough, T., Tsolacos, S., 1999, An Econometric Analysis and Forecasts of the Office Rental Cycle in the Dublin Area, Journal of Property Research, Vol. 16, No. 4, pp. 309-321.

DEWIT, I., VAN DIJK, R., 2003, The Global Determinants of Direct Office Real Estate Returns, Journal of Real Estate Finance and Economics, Vol. 26, No. 1, pp. 27 - 45.

FRANKFORT-NACHMIAS, C., 1996, Research Methods in the Social Sciences, Auckland, Hodder Arnold Ltd.

HeKMAN, J., 1985, Rental Price Adjustment and Investment in the Office Market, Journal of the American Real Estate and Urban Economics Association, Vol. 13, No.1, pp. 32-47.

Hendershott, P., LiZIERI, C., MAtysiAK, G., 1998, The Working of the London Office Market: Model Estimation and Simulation, Real Estate Research Institute, WP - 63.

HuI, E.C.M., YU, K. H., 2006, The Dynamics of Hong Kong's Office Rental Market, International Journal of Strategic Property Management, Vol. 10, pp. 145-168.

Kuryj-WYsockA, O., KuryJ, J., WisnieWsKI, R., 2014, The Dynamics of Real Estate Field of Value, Real Estate Management and Valuation, Vol. 22, No. 4, pp. 105 - 113

MCCATney, J., 2012, Short and Long-run Rent Adjustment in the Dublin Office Market, Journal of Property Research, Vol. 29, No. 3, pp. 201- 226.

McGough, T., Tsolacos, S., 1999, Interactions Within the Office Market Cycle in Great Britain, Journal of Real Estate Research, Vol. 18, No. 1, pp. 219 - 231.

OrR, A. M., JONES, C., 2003, The Analysis and Prediction of Urban Office Rents, Urban Studies, Vol. 40, No. 11 , pp. $2255-2284$.

OzYuRT, S., 2014, Spatial Dependence in Commercial Property Prices: Micro Evidence from Netherlands, European Central Bank Working Paper Series No. 1627. January.

Parker, D., MacFarlane, J., Peng, V., Murray, J., 2003, Forecasting Property Market Cycles: An Application of the RICS Model to the Sydney CBD Office Market, Journal of Financial Management of Property and Construction, Vol. 8, No. 3, pp. 179 - 191.

RADZEWICZ, A., RENIGIER-BILOZOR, M., WISNIEWSKI, R., 2011, From Uncertainty to Efficiency of the Real Estate Market, The European Real Estate Society Conference.

RADZEWICZ, A., 2013, Real Estate Market System-phase Space Theory Approach, Real Estate Management and Valuation, Vol. 21, No. 4, pp. 87 - 95.

RosEN, K., 1984, Towards a Model of the Office Building Sector, Journal of the American Real Estate and Urban Economics Association, Vol. 12, No. 3, pp. 261 - 269.

SteVEnson, S., MCGARTH, O., 2003, A Comparison of Alternative Rental Forecasting Models: Empirical Tests on the London Office Market, Journal of Property Research, Vol. 20, No. 3, pp. 235 - 260.

TONElli, M., COWLEY, M., BOYD, T., 2004, Forecasting Office Building Rental Growth using a Dynamic Approach, Pacific Rim Property Research Journal, Vol. 10, No. 3, pp. 283 - 304.

UdoeKANEM, N.B., IGHALO, J.I., NuHU, M. B., 2014, Determinants of Commercial Property Rental Growth in Minna, Nigeria, European University of Lefke Journal of Social Sciences, Vol. 5, No. 1, pp. 60 - 75.

Yusof, A. M., 2001, Modelling Office Market in Malaysia, Paper presented at the Pacific Rim Real Estate Society Conference held at Adelaide, January $21^{\text {st }}-24^{\text {th }}$. 